\title{
Phosphate-Solubilizing Rhizobacteria: Diversity, Mechanisms, and Prospects in Sustainable Agriculture
}

Becky Nancy Aloo ${ }^{1,2 *}$, Ernest Rahsid Mbega ${ }^{1}$, Billy Amedi Makumba ${ }^{3}$

${ }^{1}$ Nelson Mandela African Institution of Science and Technology, Department of Sustainable Agriculture and Biodiversity Conservation, P. O. Box 447, Arusha, Tanzania

${ }^{2}$ University of Eldoret, Department of Biological Sciences, P. O. Box 1125-30100, Eldoret, Kenya

${ }^{3}$ Moi University, Department of Biological Sciences, P.O. Box 3900-30100, Eldoret, Kenya

Corresponding author: aloobecky@yahoo.com, aloob@nm-aist.ac.tz

\begin{abstract}
Phosphorus $(\mathrm{P})$ is the second-most important element after nitrogen that is required for plant growth. Although this element is abundant in most soils, it is rarely available in plant-accessible forms since most of it normally exists in soil in insoluble forms such as phosphates. In conventional agriculture, $\mathrm{P}$ is normally supplied as chemical fertilizer to satisfy plant $\mathrm{P}$ requirements. This, to a large extent, boosts plant production. However, chemical fertilizers are costly, have a huge carbon footprint, and are environmentally-unsustainable owing to the high energy requirements during their synthesis. Besides, P-containing agricultural run-offs contribute hugely to the eutrophication of water bodies and environmental degradation. Moreover, plants can consume only a small amount of chemically-supplied $\mathrm{P}$ since between 75 and $90 \%$ of this form of $\mathrm{P}$ normally get precipitated into complexes and rapidly become fixed in soil. These issues and concerns necessitate research into alternative and viable ways of supplying P to plants. Rhizobacteria have for decades been investigated in vivo and in planta as suitable tools in sustainable agriculture due to the plant-growth-promoting activities such as nutrients' solubilization, nitrogen fixation, and production of phytohormones. Although a lot of research has been done on different nutrientssolubilizing rhizobacteria and their potential in sustainable agriculture, their mechanisms of action and prospects in sustainable agriculture remain to be fully understood. This review particularly focuses on the $\mathrm{P}$ solubilizing rhizobacteria and evaluates their diversity, mechanisms of action, and prospects in sustainable agriculture based on the present and future scenario of their application. Such information is useful in determining their potential and evaluating their prospects in promoting sustainable agricultural systems.
\end{abstract}

Keywords: phosphorus solubilization; plant growth promotion; biofertilizers; sustainable agriculture; phosphorus solubilizing bacteria; rhizobacteria 


\section{Introduction}

Phosphorus (P) is the second-most important nutrient after nitrogen in terms of plant growth and development (Alori et al., 2017; Kalayu, 2019; Mitra et al., 2020; Pradhan et al., 2017). This nutrient element is important in virtually every metabolic process in plants from photosynthesis, biosynthesis of macromolecules, and respiration to energy transfer and signal transduction (Billah et al., 2019; M. S. Khan et al., 2010; S. B. Sharma et al., 2013). It is a fundamental component of enzymes, proteins, coenzymes, nucleotides, phospholipids, and nucleic acids (Alaylar et al., 2020; Kafle et al., 2019; Kalayu, 2019). According to Mitra et al., (2020), P availability also improves other basic plant functions such as cell division, cell enlargement, and transformation of starches and sugars.

Although $\mathrm{P}$ is present in most soils in large quantities, its accessibility to plants is largely limited since it occurs in complex and insoluble forms (S. B. Sharma et al., 2013), and only about $0.1 \%$ is available for plant use (Alori et al., 2017; Zhu et al., 2011). According to Mahidi et al., (2011) and Alaylar al (2020), P anions are highly reactive get immobilized through complex formation with different cations like $\mathrm{Mg}^{2+}, \mathrm{Al}^{3+}, \mathrm{Ca}^{2+}$, and $\mathrm{Fe}^{3+}$, especially under low $\mathrm{pH}$ and the fraction that is available to plants is generally very low. Consequently, $\mathrm{P}$ is often a major limiting plant nutrient in most soils (Santana et al., 2016), and artificial P fertilizers have for long been employed to cater for P deficits in agricultural farms (Mitra et al., 2020; S. B. Sharma et al., 2013). According to FAO, (2017) approximately 52.3 billion tons of P-based fertilizers are applied each year in agricultural lands. These synthetic fertilizers present a lot of problems in the environment. For instance, increased $\mathrm{P}$ from agricultural farms has been identified as a major course of eutrophication of surface body waters (C. Bhattacharyya et al., 2020; Youssef \& Eissa, 2014). Contrary to the expectation, the continuous application of $\mathrm{P}$ fertilizers has even been shown to contribute to loss of soil fertility through the constant disturbance of natural microbial ecosystems in soil (Gyaneshwar et al., 2002). The efficiency of applied chemical P fertilizers is also reported to rarely exceed $30 \%$ due to its fixation in the form of iron/aluminium phosphate in acidic soils or calcium phosphate in neutral/alkaline soils (Alori et al., 2017; Kalayu, 2019; A. Kumar et al., 2018; Satyaprakash et al., 2017). About $75-90 \%$ of the added chemical P fertilizer is precipitated by metal-cation complexes and rapidly becomes fixed or immobilized in soils and has long-term impacts on the environment in terms of eutrophication, soil fertility depletion, and carbon footprint (S. B. Sharma et al., 2013; Zhang et al., 2017). Moreover, P is a finite resource and due to its great 
demand, and it is estimated that the word's known reserves could be depleted (Leghari et al., 2016) in the current century (Cordell et al., 2009).

The realization of the aforementioned potential problems associated with chemical P fertilizers, together with the high costs involved in their manufacture has led to the search for alternative plant fertilization mechanisms (Alori et al., 2017; Zaidi et al., 2009). Plant Growth-Promoting Rhizobacteria (PGPR) are plant-root residing bacteria in symbiotic interactions that have for decades been investigated as alternative environmentally friendly and cheap plant fertilization tools (P. N. Bhattacharyya et al., 2016; P. N. Bhattacharyya \& Jha, 2012). Phosphate solubilizing bacteria (PSB) are a subset of the PGPR with the ability to solubilize complex P forms into plantaccessible forms (Pande et al., 2017; Zaidi et al., 2009). Although a lot of research has been done on different nutrients-solubilizing rhizobacteria and their potential in sustainable agriculture (Chen et al., 2006; M. S. Khan et al., 2010), their mechanisms of action and prospects in sustainable agriculture remain to be fully understood. This review focuses on the diversity, mechanisms of action, and prospects of PSB in sustainable agriculture based on the present and future scenario of their application. Such information is useful in determining their potential and evaluating their prospects in promoting sustainable agricultural systems.

\section{The diversity of $P$ solubilizing Rhizbacteria}

Numerous microorganisms, including fungi, are capable of releasing $\mathrm{P}$ from soil through solubilization and mineralization in the natural soil environment (Alori et al., 2017; P. N. Bhattacharyya \& Jha, 2012; Kafle et al., 2019). It is estimated that $50 \%$ of all bacteria in soil are capable of solubilizing P (S. B. Sharma et al., 2013), and several strains of rhizobacteria have been described and investigated in detail for their P solubilizing capabilities. According to Sharma et al., (2013), these organisms are ubiquitous but vary in density and P solubilizing abilities from soil to soil (Awais et al., 2019; Chen et al., 2006; Kalayu, 2019; Vessey, 2003). These bacteria can be isolated from rhizospheres, rhizoplane, and even non-rhizosphere soils (S. B. Sharma et al., 2013; Zaidi et al., 2009). However, they are known to be more metabolically active and better $\mathrm{P}$ solubilizers in plant rhizospheres (P. Kaur \& Purewal, 2019; A. A. Khan et al., 2009; Rafi et al., 2019; Vessey, 2003). 


\section{Table 1: Examples of rhizobacteria with $P$ solubilization potential in various plants}

\begin{tabular}{|c|c|c|}
\hline Host/Tested Plant & Bacteria & Reference \\
\hline Apple (Malus domestica) & Pseudomonas spp. & (R. Sharma et al., 2017) \\
\hline Bamboo (Dendrocalamus asper) & $\begin{array}{l}\text { Bacillus spp., Lactobacillus spp., Burkholderia } \\
\text { spp. }\end{array}$ & (Suleiman et al., 2019) \\
\hline Chilli (Capsicum annum L.) & Pseudomonas aeruginosa & (Linu et al., 2019) \\
\hline Coffee (Coffea arabica L.) & $\begin{array}{l}\text { B. megaterium, P. putida and P. fluorescens } \\
\text { Pseudomonas sp., Bacillus sp., } \\
\text { Enterobacter sp. and } \\
\text { Stenotrophomonas sp. } \\
\text { Pseudomonas chlorophis, Erwinia rapontici, } \\
\text { Bacillus sp., Serratia marcescens }\end{array}$ & $\begin{array}{l}\text { (Baliah et al., 2016) } \\
\text { Teshome et al., } 2017\end{array}$ \\
\hline $\begin{array}{r}\text { Common bean (Phaseolus } \\
\text { vulgaris) }\end{array}$ & Bacillus sp. & $\begin{array}{l}\text { (Abdelmoteleb \& Gonzalez- } \\
\text { Mendoza, 2020) }\end{array}$ \\
\hline Cotton (Gossypium sp.) & B. megaterium, P. putida and P. fluorescens & (Baliah et al., 2016) \\
\hline Drumstick tree (Moringa oleifera) & $\begin{array}{l}\text { Azotobacter chroococcum, Saccharomyces } \\
\text { cerevisiae, and Bacillus megaterium }\end{array}$ & (Zayed, 2012) \\
\hline Eggplant (Solanum melongena) & B. megaterium, P. putida and P. fluorescens & (Baliah et al., 2016) \\
\hline Faba bean (Vicia faba L.) & Serratia plymuthica & (Borgi et al., 2020) \\
\hline Lentil (Lens culnaris) & Enterobacter, Bacillus, Pseudomonas spp. & (Midekssa et al., 2015) \\
\hline Lettuce (Lactuca sativa) & Pseudomonas spp. & (Jo et al., 2019) \\
\hline \multirow[t]{14}{*}{ Maize (Zea mays) } & Bacillus subtilis & (Wang et al., 2020) \\
\hline & Burkholderia cenocepacia & (You et al., 2020) \\
\hline & Bacillus spp., Pseudomonas spp. & (Akintokun et al., 2019) \\
\hline & $\begin{array}{l}\text { Bacillus spp., Lactobacillus spp., Burkholderia } \\
\text { spp. }\end{array}$ & (Suleiman et al., 2019) \\
\hline & $\begin{array}{l}\text { Pseudomonas plecoglossida, Acromobacter } \\
\text { insolitus, Enterobacter hormaechei }\end{array}$ & (Oo et al., 2020) \\
\hline & Bacillus aryabhattai, B. subtilis & (Ahmad et al., 2019) \\
\hline & $\begin{array}{l}\text { Bacillus safensis, B. pumilus, Kocuria rosea, } \\
\text { Enterobacter aerogenes, Aeromonas veronii }\end{array}$ & (Mukhtar et al., 2020) \\
\hline & Burkholderia cepacian & (Zhao et al., 2014) \\
\hline & Pseudomonas sp., Anthrobacter nicotinovorans & (Pereira \& Castro, 2014) \\
\hline & Lysinibacillus fusiformis & (Rafique et al., 2017) \\
\hline & $\begin{array}{l}\text { B. flexus, B. megaterium, Sinorhizobium } \\
\text { melitoti }\end{array}$ & (Ibarra-Galeana et al., 2017) \\
\hline & $\begin{array}{l}\text { P. fluorescens, } P \text {. putida, Enterobacter sp., } B . \\
\text { megaterium, B. firmus, } P \text {. agglomerans }\end{array}$ & (Sarikhani et al., 2020) \\
\hline & $\begin{array}{l}\text { B. acidiceler, B. megaterium, B. pumilus, } \\
\text { B. safensis, B. simplex, Lysinibacillus } \\
\text { fusiformis, Paenibacillus cineris and } \\
\text { P. graminis }\end{array}$ & (Kadmiri et al., 2018) \\
\hline & Alcaligenes aquaticus, Burkholderia cepacia & (Pande et al., 2017) \\
\hline Mung bean/Green gram (Vigna & Pantoea agglomerans, Burkholderia anthina & (Walpola \& Yoon, 2013) \\
\hline \multirow{4}{*}{ radiata $\mathrm{L})}$. & Bacillus aryabhattai, B. subtilis & (Ahmad et al., 2019) \\
\hline & Bradyrhizobium sp., Rhizobium sp., & (Yaqub \& Shahzad, 2011) \\
\hline & Various PSB & (Kolekar et al., 2017) \\
\hline & $\begin{array}{l}\text { Pseudomonas plecoglossida, Acromobacter } \\
\text { insolitus, Enterobacter hormaechei }\end{array}$ & (Oo et al., 2020) \\
\hline Mushroom (Agaricus busporus) & $\begin{array}{l}\text { Acinetobacter baumanii, B. megaterium, } \\
\text { Paenibacillus taichungensis }\end{array}$ & (Zhang et al., 2017) \\
\hline $\begin{array}{r}\text { Oil palm tree (Elaeis } \\
\text { guineensis) }\end{array}$ & Pseudomonas fluorescens & (Fankem et al., 2006) \\
\hline Okra (Abelmoschus esculentus) & B. megaterium, P. putida and P. fluorescens & (Baliah et al., 2016) \\
\hline \multirow[t]{2}{*}{ Rice (Oryza sativa) } & $\begin{array}{l}\text { Bacillus spp., Burkholderia spp., Paenibacillus } \\
\text { sp. }\end{array}$ & \\
\hline & Bacillus, Pseudomonas & (Eramma et al., 2020) \\
\hline
\end{tabular}




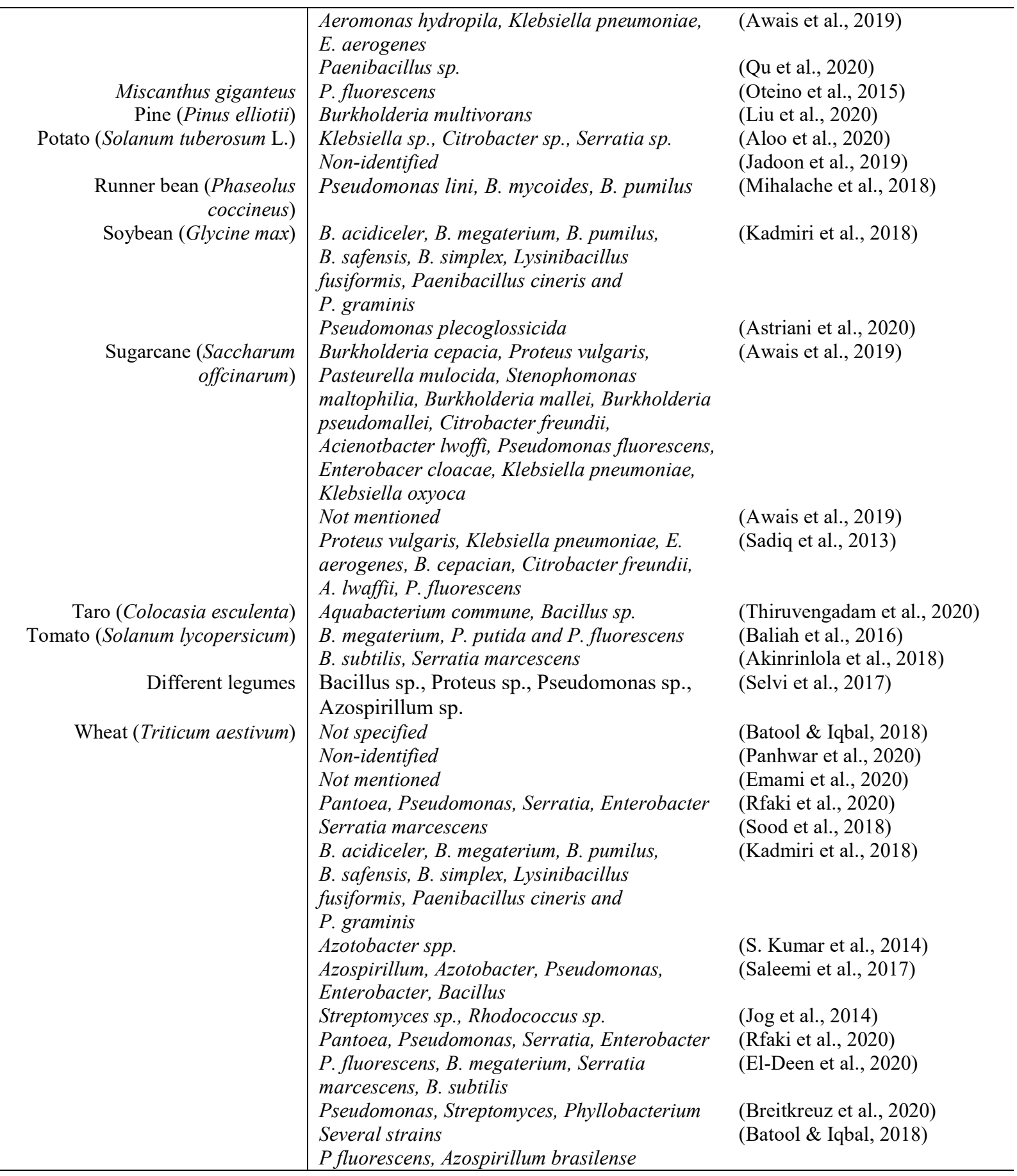

The PSB are present in almost all soils but their numbers vary depending upon soil and climatic conditions (Rafi et al., 2019). Species of Pseudomonas, Agrobacterium, Bacillus (Babalola \& Glick, 2012), Rhizobium, Enterobacter (Zaidi et al., 2009), Alcaligenes sp., Aerobactor aerogenes, Achromobacter sp., and Burkholderia sp.(Pande et al., 2017) are among the most common plant root residing $\mathrm{P}$ solubilizers. Others include Rhodococcus, Arthrobacter, Serratia, 
Chryseobacterium, Gordonia, Phyllobacterium, Delftia sp. (Chen et al., 2006), Enterobacter, Pantoea, Klebsiella (Chung et al., 2005), Micrococcus, Flavobacterium, Enterobacter, Vibrio, Chryseobacterium, Xanthobacter, Erwinia, Acinetobacter, Pantoea, Burkholderia, and Achromobacter (S. B. Sharma et al., 2013).

Mesorhizobium (Oteino et al., 2015), Aeromonas, Mycobacterium, Acetobacter, Corynebacterium, Gluconacetobacter, Achromobacter, Escherichia and Ralstonia, have also been associated with P solubilization and the subsequent increase in plant growth and yield (P. Kaur \& Purewal, 2019). Furthermore, many plant root residing PSB have also been isolated from stressed environments for example the halophilic bacteria Kushneria sinocarni isolated from the sediment of Daqiao saltern on the eastern coast of China, which may be useful in salt-affected agricultural soils (Etesami \& Maheshwari, 2018; Zhu et al., 2011).

Table 1 provides examples of root residing bacteria with $\mathrm{P}$ solubilization potential in various plants as reported by several authors. Studies show that the diversity of the PSB is highly varied in different ecological niches and there is ample scope to identify many new potent isolates from varied environments in the coming times (S. B. Sharma et al., 2013). The bacteria involved in P solubilization are numerous and probably more than $99 \%$ of them have not been successfully cultured. In this regard, culture-independent methods that are more precise, reproducible, and nondependent on culture conditions could be handier in understanding their functions and ecology (Alaylar et al., 2020). However, such methods cannot exhaustively indicate the quantity of $\mathrm{P}$ solubilizers in soils, and much of these bacteria remain unexplored (A. Kumar, 2016).

Symbiotic nitrogenous rhizobia which are known to be widely associated with the root nodules of various leguminous plants can also solubilize P (Bechtaoui et al., 2019; A. A. Khan et al., 2009; Pande et al., 2017; Qin et al., 2011; Walpola \& Yoon, 2013; Zaidi et al., 2009). Some of these species have been shown to produce various organic acids which are highly associated with $\mathrm{P}$ solubilization. For instance, while characterizing rhizobia isolated from Arachis hypogaea grown under stressed environments, Khalid et al., (2020), established the P solubilization potential of eight rhizobia through the production of organic acids. Similar results have also been reported by Harsitha et al. (2020), Nagalingam et al., (2020), and Sijilmassi et al., (2020) in different plants. 


\section{Mechanisms of $P$ solubilizing Plant Root Residing Bacteria}

The mechanisms of $\mathrm{P}$ solubilization depends on the $\mathrm{P}$ forms in soil, whether organic or inorganic. While inorganic $\mathrm{P}$ forms occur in soil as insoluble mineral complexes, mostly after the application of chemical fertilizers, organic P is mostly constituted in organic matter (S. B. Sharma et al., 2013). According to Alori et al., (2017), organic P can be as high as $30-50 \%$ of the total $\mathrm{P}$ in soil. The most common form of organic $\mathrm{P}$ is phytate/inositol $\mathrm{P}$ but are largely unavailable to plants because they lack phytase activities (Alori et al., 2017; Kafle et al., 2019; A. Kumar, 2016). Other organic $\mathrm{P}$ compounds that have include phosphomonoesters, phosphodiesters, phospholipids, nucleic acids, and phosphotriesters (A. Kumar, 2016).

Rhizobacteria of many plants have been shown to possess the ability to mineralize both organic and inorganic complex $\mathrm{P}$ compounds. For instance, the ability of several rhizobacterial genera to solubilize inorganic $\mathrm{P}$ compounds such as tricalcium phosphate, dicalcium phosphate, and rock phosphate is largely documented (Billah et al., 2019; El-Deen et al., 2020)From experiments, the principal mechanism is the production of mineral dissolving compounds such as organic acids, siderophores, protons, hydroxyl ions, and $\mathrm{CO}_{2}$ (Satyaprakash et al., 2017; S. B. Sharma et al., 2013). Nevertheless, the main mechanism of inorganic P solubilization is largely proposed to be by organic acids (Billah et al., 2019; Pande et al., 2017; Rafi et al., 2019; Walia et al., 2017), whose carboxyl and hydroxyl ions act by lowering soil $\mathrm{pH}$, chelating cations like iron, aluminum, and calcium ions bound to $\mathrm{P}$, competing with $\mathrm{P}$ for adsorption sites in soil and/or forming soluble complexes with metal ions associated with P (P. N. Bhattacharyya et al., 2016; Billah et al., 2019; S. T. Patel \& Minocheherhomji, 2018; Pradhan et al., 2017; S. B. Sharma et al., 2013). These acids that compete for fixation sites of $\mathrm{Al}$ and Fe insoluble oxides are called chelates (Kulayu et al., 2019). One such acid which is a powerful chelator of calcium is 2-ketogluconic acid (Walpola \& Yoon, 2013). Organic acids may also directly dissolve mineral P by anion exchange (Satyaprakash et al., 2017). These acids are products of microbial metabolism such as oxidative respiration or fermentation of organic sources (Satyaprakash et al., 2017; Zaidi et al., 2009).

The organic acids that solubilize phosphates are primarily citric, lactic, gluconic, 2-ketogluconic, oxalic, glyconic, acetic, malic, fumaric, succinic, tartaric, malonic, glutaric, propionic, butyric, glyoxalic, and adipic acid (A. Kumar et al., 2018; Satyaprakash et al., 2017). 


\section{Table 2: Organic acids produced by various phosphate-solubilizing rhizobacteria}

\begin{tabular}{|c|c|c|c|}
\hline Host/test plant & Bacteria & Organic acid(s) & Reference \\
\hline Mangroves & $\begin{array}{l}\text { Bacillus amyloliquefaciens, Bacillus } \\
\text { licheniformis, Bacillus atrophaeus, Paenibacillus } \\
\text { macerans, Pseudomonas aeruginosa }\end{array}$ & Lactic, isovaleric, isobutyric, acetic & (Vazquez et al., 2000) \\
\hline $\begin{array}{r}\text { Oil palm tree } \\
\text { (Elaeis } \\
\text { guineensis) }\end{array}$ & Pseudomonas fluorescens & Citric, malic, tartaric, gluconic & (Fankem et al., 2006) \\
\hline $\begin{array}{r}\text { Sunflower } \\
\text { (Helianthis } \\
\text { annuus L.) }\end{array}$ & Enterobacter sp. Fs-11 & Malic acid, gluconic & (Shahid et al., 2012) \\
\hline Several Legumes & $\begin{array}{l}\text { Bacillus sp., Proteus sp., Pseudomonas sp., } \\
\text { Azospirillum sp. }\end{array}$ & $\begin{array}{l}\text { Citric, malic, succinic, fumaric, tartaric, gluconic, } \\
\text { succinic, ketobutyric, glyoxalic, glutaric }\end{array}$ & (Selvi et al., 2017) \\
\hline Coffea arabica & $\begin{array}{l}\text { Pseudomonas chlorophis, Erwinia rapontici, } \\
\text { Bacillus sp., Serratia marcescens }\end{array}$ & 2-ketogluconic, gluconic, acetic, propionic & (Muleta et al., 2013) \\
\hline $\begin{array}{r}\text { Miscanthus } \\
\text { giganteus }\end{array}$ & Pseudomonads & Gluconic & (Oteino et al., 2015) \\
\hline Mangrove & Serratia sp. & Lactic, malic, acetic & (Behera et al., 2016, 2017) \\
\hline Chickpea & Burkholderia & gluconic, acetic, and citric & (Valverde et al., 2006) \\
\hline $\begin{array}{r}\text { Lentil (Lens } \\
\text { culnaris Medik.) }\end{array}$ & $\begin{array}{l}\text { Enterobacter, Bacillus, } \\
\text { Pseudomonas spp. }\end{array}$ & Not identified & (Midekssa et al., 2015) \\
\hline Maize (Zea mays) & Burkholderia cepacian, Alcaligenes aquatilis & Gluconic, formic, citric & (Pande et al., 2017) \\
\hline \multirow{2}{*}{$\begin{array}{r}\text { Rice (Oryza } \\
\text { sativa) }\end{array}$} & Bacillus, Pseudomonas & Gluonic & (Eramma et al., 2020) \\
\hline & Enterobacter sp. & Citric, lactic, tartaric & (Dash \& Dangar, 2019) \\
\hline Apples & Pseudomonas spp. & $\begin{array}{l}\text { Schimic, succinic, malonic, citric, malic, quinic, } \\
\text { tartaric, fumaric and lactic }\end{array}$ & (R. Sharma et al., 2017) \\
\hline Runner bean & Pseudomonas lini, B. mycoides, B. pumilus & Isocitric, Tartaric, Succinic & (Mihalache et al., 2018) \\
\hline Araucaria & Pantoea agglomerans & $\begin{array}{l}\text { Gluconic, oxalic, tartaric, malic, acetic, citric, } \\
\text { succinic }\end{array}$ & (Li et al., 2020) \\
\hline Maize & Not determined & Malic & (Fitriatin et al., 2020) \\
\hline $\begin{array}{r}\text { Wheat (Triticum } \\
\text { aestivum) }\end{array}$ & Pantoea, Pseudomonas, Serratia, Enterobacter & Oxalic, citric, gluconic, succinic, fumaric, acetic & (Rfaki et al., 2020) \\
\hline $\begin{array}{r}\text { Lettuce (Lactuca } \\
\text { sativa) }\end{array}$ & Pseudomonas & Carboxylic, gluconic & (Jo et al., 2019) \\
\hline $\begin{array}{r}\text { Mung bean (Vigna } \\
\text { radiata L.) }\end{array}$ & $\begin{array}{l}\text { Acinetobacter sp. Pseudomonas sp., } \\
\text { Microbacterium sp. }\end{array}$ & Gluconic, acetic & (Hakim et al., 2020) \\
\hline
\end{tabular}

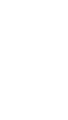


Others include isovaleric acid, lactic acid, isobutyric acid, and oxalic acid (C. Kaur et al., 2016; Rawat et al., 2018). Table 2 shows different forms of organic acids produced by several PSB associated with different plants. Among these organic acids, gluconic acid is the most common one implicated in P solubilization (Alori et al., 2017; S. B. Sharma et al., 2013). Different organisms produce different types and quantities of organic acids (Kalayu, 2019; Rafi et al., 2019; Satyaprakash et al., 2017), which is also dependent on the type of carbon available for the microbes (D. Patel \& Goswami, 2020). Subsequently, they differ extensively in their P solubilization efficiency (Rafi et al., 2019). (Kalayu, 2019).

According to Delfim et al., (2018), the efficiency of P solubilization is greatly dependent on the type of organic acid produced and its concentration. However, evidence suggests that the quality of acids rather than their quantity is more important for P solubilization because the efficiency of solubilization is dependent upon the strength and nature of acids(Kalayu, 2019). In the same light, tri- and dicarboxylic acids are more effective as compared to monobasic and aromatic acids, and aliphatic acids are also found to be more effective in phosphate solubilization compared to phenolic, citric, and fumaric acids (Mahidi et al., 2011; Walpola \& Yoon, 2013). Additionally, the simultaneous production of different organic acids may contribute to greater $\mathrm{P}$ solubilization potential (Marra et al., 2012).

Gram-negative bacteria are reportedly more effective P solubilizers than Gram-positive bacteria due to the release of diverse organic acids into the surrounding soil (A. Kumar et al., 2018), but more light needs to be shed on this. Apart from organic acids, other chelating substances, and inorganic acids such as sulphiridic, sulfuric, nitric, and carbonic acids (Pande et al., 2017; Walpola \& Yoon, 2013) are also considered as alternative P solubilizing mechanisms of PSB, but their contribution and effectiveness in this regard are limited (Alori et al., 2017; Pradhan et al., 2017). Nevertheless, this explains why P solubilization by rhizobacteria can occur without the production of organic acids (Chen et al., 2006).

A second and major component of soil $\mathrm{P}$ is organic matter which contains organic $\mathrm{P}$ forms which may constitute $15-85 \%$ of the total P in most soils (Dash et al., 2017). The solubilization of organic P forms occurs through mineralization by several PSB (Dash et al., 2017). The mineralization process is mediated by enzymes such as phosphatases and phytases (Behera et al., 2016, 2017; Dash et al., 2017; Maougal et al., 2014). Phosphatases, which may be acid or alkaline in nature based on their pH optima (Jorquera et al., 2011), are nonspecific enzymes that are 
secreted by bacterial cells and require P as substrates (Beech et al., 2001) and function by dephosphorylating phospho-ester or phosphor-anhydride bonds of organic matter (Alori et al., 2017; Dash et al., 2017; S. B. Sharma et al., 2013). These enzymes have been studied in many bacterial genera including Bacillus, Citrobacter, Enterobacter, Klebsiella, Proteus, Pseudomonas, Rhizobium, and Serratia (Behera et al., 2016, 2017; C. Bhattacharyya et al., 2020). Phytases, on the other hand, mediate the degradation of phytate or phytic acid which is the major component of organic P in soil (Dash et al., 2017; Pradhan et al., 2017). Plants generally cannot acquire phosphorus directly from phytate, however, the presence of PSM in the rhizosphere may compensate for this (Richardson \& Simpson, 2011). Some plant root residing bacteria that can mineralize complex organic phosphates through the production of extracellular enzymes like phosphor-esterases, phosphor-diesterases, phytases, and phospholipases are members of Bacillus and Streptomyces spp. (A. A. Khan et al., 2009). Other enzymes involved in organic P mineralization include phosphonatases (Dash et al., 2017; V. Kumar et al., 2013), and lyases (Dash et al., 2017; Salimpour et al., 2010) which function by cleaving organo-phosphonates. Considering the positive impact of such enzymes in the dissolution of complex organic P forms into plantusable forms, it highly desirable that PSB that reduces such enzymes be developed into inoculants for plant biofertilization practices.

Apart from inorganic P solubilization by acidification and organic P solubilization by bacterial enzymes, several other bacterial mechanisms have also been suggested to bring about $\mathrm{P}$ solubilization. One important theory of the solubilization of organic $\mathrm{P}$ is the sink theory. Microorganisms in the presence of labile $\mathrm{C}$ serve as a sink for $\mathrm{P}$, by rapidly immobilizing it even in low P soils; PSB become a source of P to plants upon its release from their cells. Release of P immobilized by PSB primarily occurs when cells die due to changes in environmental conditions, starvation, or predation (S. B. Sharma et al., 2013). Apart from this, bacterial siderophores which are complexing agents with a high affinity for iron have also been considered to take part in $\mathrm{P}$ solubilization (A. Kumar et al., 2018; Parker et al., 2005; Satyaprakash et al., 2017). However, this mechanism of $\mathrm{P}$ solubilization has not been widely investigated, and the production of siderophores by PSB has not yet been directly linked to P solubilization. Considering the dominance of mineral dissolution over ligand exchange by organic acid anions as a P solubilization mechanism (Parker et al., 2005), the potential role of siderophore in P solubilization should be given more attention. 
Microbial exopolysaccharides (EPS) which are polysaccharide polymers excreted by microbes into their environment (Walia et al., 2017) have also been linked to P solubilization (Yi et al., 2008). The authors established a strong indication of P solubilization by Arthrobacter, Azotobacter, and Enterobacter spp. that produced EPS were also shown to increase the quantities of soluble P. This is indeed an interesting phenomenon but more studies are necessary to understand the relationship between EPS production and phosphate solubilization.

It is clear that P solubilization by PSB has been a subject of analysis and research for a long time and yet still seems to be in its infancy. It occurs through different mechanisms and there is considerable variation amongst the organisms in this respect. Each organism can act in one or more than one way to bring about the solubilization of insoluble P. Though it is difficult to pinpoint a single mechanism, the production of organic acids and consequent $\mathrm{pH}$ reduction appears to be of great importance.

\section{Prospects of $\mathbf{P}$ solubilizing Rhizobacteria in Sustainable Agricultures}

There is no doubt that artificial $\mathrm{P}$ fertilizers can improve plant mineral $\mathrm{P}$ nutrition but the resources used to make these fertilizers are finite and dwindling. Moreover, P availability to plants is still limited even in chemical-P supplied soils due to fixation. About $75-90 \%$ of the added chemical $\mathrm{P}$ fertilizer is precipitated by metal-cation complexes and rapidly becomes fixed in soils and has long-term impacts on the environment in terms of eutrophication, soil fertility depletion, and carbon footprint (S. B. Sharma et al., 2013).

For decades, researchers worldwide have vigorously been searching for alternative plant fertilization mechanisms. This has paved ways for the identification of efficient PGP rhizobacteria and their development into biofertilizers by formulating them into different carrier materials. The use of such organisms is greatly advocated for in this regard because they are environmentallyfriendly and relatively cheap compared to their artificial counterparts (Babalola \& Glick, 2012). According to Pradhan et al, (2017) these microorganisms can also protect plants against phytopathogens and have a high cost-benefit ratio because of low-cost production technologies. This is because their formulation largely involves the use of agribusiness waste products which are readily and cheaply available. The use of these waste products in the formulation of biofertilizers including the PSB not only contribute to environmental sustainability by providing eco-friendly plant fertilization mechanism but also by reducing the quantity of wastes in the environment. 


\section{Table 3: Examples of commercially available Phosphate Solubilizing Rhizobacterial biofertilizers in different countries}

\begin{tabular}{|c|c|c|c|c|c|}
\hline Product & Bacteria & Company & Crop & Country & Reference \\
\hline $\begin{array}{l}\text { Anubhav liquid } \\
\text { formulation }\end{array}$ & B. coagulans & $\begin{array}{l}\text { Anand Agricultural } \\
\text { University }\end{array}$ & All crops & India & (Vyas et al., 2017) \\
\hline Azo-N Plus* & $\begin{array}{l}\text { Azospirillum brasilense, } \\
\text { Azospirillum lipoferum, } \\
\text { Azotobacter chroococum }\end{array}$ & $\begin{array}{l}\text { BioControl } \\
\text { Products SA (Pty) } \\
\text { Ltd }\end{array}$ & Not specified & $\begin{array}{l}\text { South } \\
\text { Africa }\end{array}$ & (Rodrigues et al., 2008) \\
\hline Azo-N* & $\begin{array}{l}\text { Azospirillum brasilense, } \\
\text { Azospirillum lipoferum }\end{array}$ & $\begin{array}{l}\text { BioControl } \\
\text { Products SA (Pty) } \\
\text { Ltd }\end{array}$ & Not specified & $\begin{array}{l}\text { South } \\
\text { Africa }\end{array}$ & (Rodrigues et al., 2008) \\
\hline Bac up* & B. subtilis & $\begin{array}{l}\text { Biological control } \\
\text { product Ltd }\end{array}$ & Not specified & $\begin{array}{l}\text { South } \\
\text { Africa }\end{array}$ & $\begin{array}{l}\text { (Ahemad \& Khan, 2010; Mohammadi \& } \\
\text { Sohrabi, 2012; Parmar \& Sindhu, 2013) }\end{array}$ \\
\hline Bio Gold* & $\begin{array}{l}\text { P. fluorescens, Azotobacter } \\
\text { chroococcum }\end{array}$ & Bio Power Lanka & $\begin{array}{l}\text { Cardamom, potato, } \\
\text { vegetables, fruits, cereals }\end{array}$ & Sri Lanka & (Mehnaz et al., 2016) \\
\hline Bio Phos ${ }^{\circledR}$ & B. megaterium & Bio Power Lanka & Not mentioned & Sri Lanka & (Mehnaz et al., 2016) \\
\hline Bioativo* & $P G P R$ consortia & Embrafos Ltd & $\begin{array}{l}\text { Bean, maize, sugarcane, } \\
\text { rice, carrot, cotton, } \\
\text { maize, citrus, tomatoes, } \\
\text { soybean }\end{array}$ & Brazil & $\begin{array}{l}\text { (García-Fraile et al., 2015; Odoh et al., } \\
\text { 2019) }\end{array}$ \\
\hline Phylazonit & $\begin{array}{l}\text { Azotobacter chroococcum, } \\
\text { B. megaterium }\end{array}$ & $\begin{array}{l}\text { Ministry of } \\
\text { Agriculture }\end{array}$ & Not specified & Hungary & (Dash et al., 2017) \\
\hline $\begin{array}{l}\text { Bio-phos, Humi- } \\
\text { phos }\end{array}$ & Various non-identified PSB & $\begin{array}{l}\text { Auriga Group of } \\
\text { companies }\end{array}$ & Not specified & Pakistan & (Mehnaz et al., 2016) \\
\hline $\begin{array}{l}\text { Biomix, Gmax } \\
\text { PGPR }\end{array}$ & $\begin{array}{l}\text { Aotobacter, P. fluorescens, } \\
\text { Phosphobacteria }\end{array}$ & $\begin{array}{l}\text { GreenMax } \\
\text { Agrotech }\end{array}$ & $\begin{array}{l}\text { Several plants and field } \\
\text { crops }\end{array}$ & India & (Odoh et al., 2019) \\
\hline Bio-N* & Azotobacter spp. & Nutri-Tech Solution & Australia & Australia & (Adeleke et al., 2019) \\
\hline Biophos & Non-identified PSB & Ajay Bio-Tech Ltd & Various crops & India & http://www.ajaybio.in/prodpro.htm \\
\hline $\begin{array}{l}\text { Biophos, Get-Phos, } \\
\text { Reap P, } \\
\text { Phosphonive }\end{array}$ & $\begin{array}{l}\text { B. megaterium var. } \\
\text { phosphaticum }\end{array}$ & Not mentioned & All crops & India & (Thomas \& Singh, 2019) \\
\hline B-RUS, Extrasol* & B. subtilis & $\begin{array}{l}\text { Ag-Chem Africa } \\
\text { (Pty) Ltd }\end{array}$ & Not specified & $\begin{array}{l}\text { South } \\
\text { Africa }\end{array}$ & $\begin{array}{l}\text { (Ahemad \& Khan, 2010; Mohammadi \& } \\
\text { Sohrabi, 2012; Parmar \& Sindhu, 2013) }\end{array}$ \\
\hline Calphorous & Non-identified PSB & $\begin{array}{l}\text { Camson Bio } \\
\text { Technologies } \\
\text { Limited }\end{array}$ & $\begin{array}{l}\text { Legumes, cereals, } \\
\text { vegetables }\end{array}$ & India & $\begin{array}{l}\text { http://wwwcamsonbiotechologies.com/prod } \\
\text { ucts/bio_fertilizers and_stimulants.htm }\end{array}$ \\
\hline Composter* & Bacillus sp. & $\begin{array}{l}\text { BioControl } \\
\text { Products SA (Pty) } \\
\text { Ltd }\end{array}$ & Not specified & $\begin{array}{l}\text { South } \\
\text { Africa }\end{array}$ & $\begin{array}{l}\text { (Mohammadi \& Sohrabi, 2012; Parmar \& } \\
\text { Sindhu, 2013) }\end{array}$ \\
\hline Ecosoil & P. aureofaciens & $\begin{array}{l}\text { ZECH Umwelt } \\
\text { GmbH }\end{array}$ & $\begin{array}{l}\text { Cucumber, tomato, } \\
\text { wheat, barley }\end{array}$ & Germany & (D. Patel \& Goswami, 2020) \\
\hline Ferti-Bio* & PGPR consortia & $\begin{array}{l}\text { Microbial } \\
\text { Biotechnologies }\end{array}$ & $\begin{array}{l}\text { Rice, wheat, corn, cotton, } \\
\text { sugarcane, vegetables }\end{array}$ & Pakistan & $\begin{array}{l}\text { (Kennedy et al., 2004; Mehnaz et al., 2016; } \\
\text { Mishra \& Arora, 2016) }\end{array}$ \\
\hline
\end{tabular}




\begin{tabular}{|c|c|c|c|c|c|}
\hline $\begin{array}{l}\text { Gmax, } \\
\text { Phosphomax, Astha } \\
\text { PSB }\end{array}$ & B. megaterium, P. striata & $\begin{array}{l}\text { Varsha Bioscience } \\
\text { and Technology }\end{array}$ & All crops & India & $\begin{array}{l}\text { (Pallavi et al., 2017) } \\
\text { http://www.varshabioscience.com/products/ } \\
\text { phosphomax.html }\end{array}$ \\
\hline Rhizosum ${ }^{\circledR} \mathrm{P}$ & B. megaterium & $\begin{array}{l}\text { Biosym } \\
\text { Technologies }\end{array}$ & Not specified & India & (Mehnaz et al., 2016) \\
\hline Sardar Biofertilizer & $\begin{array}{l}\text { Azotobacter, Azospirillum, } \\
\text { and non-identified PSB }\end{array}$ & $\begin{array}{l}\text { Gujarat State } \\
\text { Fertilizers and } \\
\text { Chemicals }\end{array}$ & All types of crops & India & $\begin{array}{l}\text { http://www.gsfclimited.com/bio_fertilizers.a } \\
\text { sp?mnuid=3\&fid=32 }\end{array}$ \\
\hline Signum & $\begin{array}{l}\text { Rhizobacter sp., } \\
\text { Bradyrhizobium sp. }\end{array}$ & Rhizobacter S. A. & Legumes and cereals & Argentina & $\begin{array}{l}\text { http://www.rhizobacter.com/argentian/prod } \\
\underline{\text { uctos/ }}\end{array}$ \\
\hline Soil Vital Q* & $\begin{array}{l}\text { B. subtilis, B. thuringiensis, } \\
\text { Azotobacter chroococum, } \\
\text { Lactobacillus sp., } \\
\text { Pseudomonas fluorscens }\end{array}$ & $\begin{array}{l}\text { Biological control } \\
\text { Products SA (Pty) } \\
\text { Ltd }\end{array}$ & Not specified & $\begin{array}{l}\text { South } \\
\text { Africa }\end{array}$ & $\begin{array}{l}\text { (Ahemad \& Khan, 2010; Mohammadi \& } \\
\text { Sohrabi, 2012; Parmar \& Sindhu, 2013) }\end{array}$ \\
\hline SoilFix* & $\begin{array}{l}\text { Bravibacillus laterosporus, } \\
\text { Paenibacillus } \\
\text { chitinolyticus, lysinibacillus } \\
\text { sphaericus, } \\
\text { Sporolactobacillus } \\
\text { laevolacticus }\end{array}$ & $\begin{array}{l}\text { BioControl } \\
\text { Products SA (Pty) } \\
\text { Ltd }\end{array}$ & Not specified & $\begin{array}{l}\text { South } \\
\text { Africa }\end{array}$ & (Grady et al., 2016) \\
\hline Soyflo* & Bradyrhizobium japonicum & Soygro (Pty) Ltd & Not specified & $\begin{array}{l}\text { South } \\
\text { Africa }\end{array}$ & (Tairo \& Ndakidemi, 2014) \\
\hline Symbion-P & $\begin{array}{l}\text { B. megaterium var } \\
\text { phosphaticum }\end{array}$ & $\begin{array}{l}\text { T. Stanes \& } \\
\text { Company Limited }\end{array}$ & $\begin{array}{l}\text { Cereals, legumes and } \\
\text { vegetable crops }\end{array}$ & India & $\frac{\text { http://www.tstanes.com/products-symbion- }}{\text { p.html }}$ \\
\hline Twin $\mathrm{N}$ & $\begin{array}{l}\text { Azorhizobium sp., Azoarcus } \\
\text { sp., Azospirillum sp. }\end{array}$ & Mapleton Ltd & Legumes and cereals & Australia & $\begin{array}{l}\text { (Mehnaz et al., 2016; Mishra \& Arora, } \\
\text { 2016; Rodrigues et al., 2008) }\end{array}$ \\
\hline Vault NP* & Bradyrhizbium japonicum & Becker Underwood & Legumes & USA & (Tairo \& Ndakidemi, 2014) \\
\hline Xin Cheng Li & $\begin{array}{l}\text { B. mucilaginous, B. subtilis, } \\
\text { Phosphobacteria }\end{array}$ & $\begin{array}{l}\text { CBF China Bio- } \\
\text { Fertilizer AG }\end{array}$ & Not mentioned & China & (Mishra \& Arora, 2016) \\
\hline Phylazonit M* & $\begin{array}{l}\text { Azotobacter chrococcum, } B \text {. } \\
\text { megaterium }\end{array}$ & $\begin{array}{l}\text { Ministry of } \\
\text { Agriculture }\end{array}$ & Not mentioned & Hungary & (Dash et al., 2017) \\
\hline
\end{tabular}


Microorganisms are an integral part of the phosphorus cycle (Kalayu, 2019), and the beneficial effects of PSB inoculation have been described in many plants and they are already being applied as effective inoculants in agronomic practices to increase the productivity of many crops (P. N. Bhattacharyya et al., 2016; Pradhan et al., 2017). According to Alori et al., (2017), the PSB technology can improve soil fertility and help in the realization of sustainable agriculture with minimized usage of artificial fertilizers and P use efficiency in agricultural lands can be improved through inoculation of PSM (Alaylar et al., 2020; Kalayu, 2019).

The use of PSB as biofertilizers for agriculture enhancement has been a subject of study for several years now (Kalayu, 2019; Wang et al., 2020; Zhang et al., 2017). The inoculation of PSB in soil or seed is widely reported to enhance the solubilization of applied and fixed $\mathrm{P}$ in soil, resulting in better crop yield (Alori et al., 2017; Billah et al., 2019; R. Sharma et al., 2017; S. B. Sharma et al., 2013; Wang et al., 2020; Zhang et al., 2017). Many studies have reported correlations between the inoculation of PSB in soil with plant height, biomass production, and phosphorus content in plants that have been reported (Santana et al., 2016).

Several PSB are commercially available in the market as formulated products or biofertilizers (Goswami et al., 2016). The first commercial biofertilizer called "Phosphobacterin" was formulated using Bacillus megaterium var. phosphaticum in the former Soviet Union and later on was frequently applied in East European countries and India (Mohammad et al., 2007). Table 3 presents forms of commercially available PSB biofertilizers in different countries and their trade names. Although several Gram-negative PSB such as Pseudomonas are known to competent P solubilizers, their formulation into biofertilizers is problematic because they do not bear spores, thus, have short shelf lives (D. Patel \& Goswami, 2020).

\section{Future Trends and Research Focus on P solubilizing Rhizobacteria}

Microbial mediated $\mathrm{P}$ management is an eco-friendly and cost-effective approach for the sustainable development of crops (S. B. Sharma et al., 2013). The involvement of rhizobacteria in $\mathrm{P}$ solubilization is well documented. Most of the studies have however centered on the isolation of these microorganisms from the rhizospheric soil and the in vitro evaluation of their activities, with limited investigations under filed conditions (Pradhan et al., 2017).

Apart from P solubilization, various rhizobacterial PSB possess other PGP traits such as nitrogen fixation, production of PGP hormones and siderophores as well as the solubilization of other plant required nutrients like zinc and potassium (Varma et al., 2017; Yildirim et al., 2011; Zaidi et al., 
2009). Such PSB can be more advantageous to plants as opposed to those that possess only the $P$ solubilization function. For instance, PSB that produce PGP hormones apart from increasing P availability in the rhizosphere can also increase root development to enhance the uptake of more P (Etesami \& Beattie, 2018; Etesami \& Maheshwari, 2018). An alternative approach for the use of PSM as microbial inoculants is either the use of mixed cultures or co-inoculation with other microorganisms with other capabilities.

Molecular research has identified and characterized some genes that are involved in mineral and organ P solubilization. Nevertheless, studies on P solubilization and PSB at the genetic level are still inconclusive (Pradhan et al., 2017). The manipulation of such genes through genetic engineering and their expression in selected rhizobacterial strains opens a promising frontier for obtaining PSB with improved P-solubilizing abilities as agricultural inoculants (Pradhan et al., 2017). Indeed, such advances can be superior since a single engineered inoculant can be suitable for the inoculation of several crops. Molecular-based techniques offer the new prospect for the quantification of target gene expression with high potential in plant rhizosphere soils (Alaylar et al., 2019, 2020). Microarrays can also provide a further application for the estimation of the diversity surrounding particular traits or functional groups of microorganisms (Richardson \& Simpson, 2011), including the PSB. Together, these tools deliver new opportunities in the ecology of microbial communities and assess the survival and perseverance of specific inoculants under diverse environmental conditions. Biotechnological approaches can develop more knowledge about PSB mechanisms of actions of PSB and pave way for the development of more successful potential in them.

As far as field trials are concerned the establishment and performance of these PSM inoculate developed in the laboratory are largely hampered by environmental variables including salinity, $\mathrm{pH}$, moisture, temperature, and climatic conditions of the soil (Walia et al., 2017). Moreover, the inocula developed from a particular soil fail to function as effectively in soils having different properties (S. B. Sharma et al., 2013). Hence the necessity to study PSM activity in correlation with these factors before PSM application as a biofertilizer. The growing need for the discovery of new strains of PSMs necessitates the replacement of the time-consuming and less sensitive conventional methods with alternative approaches that are more accurate, reliable, less time consuming, and show reproducible results (Alaylar et al., 2020). The current approaches and developments in our understanding of the functional diversity, rhizosphere colonizing ability, and 
mode of actions of PSB are likely to facilitate their application as reliable options in the management of sustainable agricultural systems.

\section{Conclusion}

Phosphorus is an important limiting factor in agriculture. Considering the cost and the negative effects of chemical fertilizers, efforts should be focused on PSB technology which offers an excellent opportunity to reduce chemical-based agriculture. Although the potential exists for developing such inoculants, their widespread application remains largely limited by the lack of understanding of their diversity, ecology, and population dynamics in soil, and by inconsistent performance over a range of environments. Current and future developments in understanding them fully are likely to facilitate their use as reliable components in agricultural systems. Furthermore, researchers need to address issues like efficacy, delivery systems, and nutritional aspects to reap maximum benefits from their application.

\section{Funding}

This research did not receive any specific grant from funding agencies in the public, commercial, or not-for-profit sectors

\section{References}

Abdelmoteleb, A., \& Gonzalez-Mendoza, D. (2020). Isolation and Identification of Phosphate Solubilizing Bacillus spp. From Tamarix ramosissima Rhizosphere and Their Effect on Growth of Phaseolus vulgaris Under Salinity Stress. Geomicrobiology Journal, 1-8. https://doi.org/10.1080/01490451.2020.1795321

Adeleke, R. A., Raimi, A. R., Roopnarain, A., \& Mokubedi, S. M. (2019). Status and Prospects of Bacterial Inoculants for Sustainable Management of Agroecosystems. In B. Giri, R. Prasad, Q. S. Wu, \& A. Varma (Eds.), Biofertilizers for Sustainable Agriculture and Environment (pp. 137-172). Springer International Publishing. https://doi.org/10.1007/978-3-03018933-4_7

Ahemad, M., \& Khan, M. (2010). Influence of Selective Herbicides on Plant Growth-Promoting Traits of Phosphate solubilising Enterobacter asburiae strain PS2. Research Journal of Microbiology, 5(9), 849-857. 
Ahmad, M., Adil, Z., Hussain, A., Mumtaz, M. Z., Nafees, M., Ahmad, I., \& Jamil, M. (2019). Potential of Phosphate Solubilizing Bacillus Strains for improving growth and nutrient uptake in Mungbean and Maize crops. 56(2), 283-289.

Akinrinlola, R. J., Yuen, G. Y., Drijber, R. A., \& Adesemoye, A. O. (2018). Evaluation of Bacillus strains for plant growth promotion and predictability of efficacy by in vitro physiological traits. International Journal of Microbiology, 11, 5686874. https://doi.org/10.1155/2018/5686874

Akintokun, A. K., Ezaka, E., Akintokun, P. O., \& Taiwo, L. B. (2019). Isolation, Screening and Response of Maize to Plant Growth Promoting Rhizobacteria Inoculants. Scientia Agriculturae Bohemica, 50(3), 181-190. https://doi.org/10.2478/sab-2019-0025

Alaylar, B., Egamberdieva, D., Gulluce, M., Karadayi, M., \& Arora, N. K. (2020). Integration of molecular tools in microbial phosphate solubilization research in agriculture perspective. World Journal of Microbiology and Biotechnology, 36(7), 93. https://doi.org/10.1007/s11274-020-02870-x

Alaylar, B., Güllüce, M., Karadayi, M., \& Isaoglu, M. (2019). Rapid Detection of PhosphateSolubilizing Bacteria from Agricultural Areas in Erzurum. Current Microbiology, 76(7), 804-809. https://doi.org/10.1007/s00284-019-01688-7

Aloo, B. N., Mbega, E. R., Makumba, B. A., Hertel, R., \& Danel, R. (2020). Molecular identification and in vitro plant growth-promoting activities of culturable Potato (Solanum tuberosum L.) rhizobacteria in Tanzania. Potato Research. https://doi.org/10.1007/s11540020-09465-x

Alori, E. T., Glick, B. R., \& Babalola, O. O. (2017). Microbial phosphorus solubilization and its potential for use in sustainable agriculture. Frontiers in Microbiology, 8, 971. https://doi.org/10.3389/fmicb.2017.00971

Astriani, M., Zubaidah, S., Abadi, A. L., \& Suarsini, E. (2020). Pseudomonas plecoglossicida as a novel bacterium for phosphate solubilizing and indole-3-acetic acid-producing from soybean rhizospheric soils of East Java, Indonesia. Biodiversitas, 21(2), 578-586. https://doi.org/10.13057/biodiv/d210220

Awais, M., Tariq, M., Ali, Q., Khan, A., Ali, A., Nasir, I. A., \& Husnain, T. (2019). Isolation, characterization and association among Phosphate Solubilizing bacteria from sugarcane rhizosphere. Cytology and Genetics, 53(1), 86-95. https://doi.org/10.3103/S0095452719010031 
Babalola, O. O., \& Glick, B. R. (2012). The use of Microbial Inoculants in African Agriculture: Current Practice and Future Prospects. Journal of Food, Agriculture and Environment, 10(3-4), 540-549.

Baliah, N. T., Pandiarajan, G., \& Kumar, B. M. (2016). Isolation, identification and characterization of phosphate solubilizing bacteria from different crop soils of Srivilliputtur Taluk, Virudhunagar District, Tamil Nadu. Tropical Ecology, 57(3), 465474.

Batool, S., \& Iqbal, A. (2018). Phosphate solubilizing rhizobacteria as alternative of chemical fertilizer for growth and yield of Triticum aestivum (Var. Galaxy 2013). Saudi Journal of Biological Sciences. https://doi.org/10.1016/j.sjbs.2018.05.024

Bechtaoui, N., Raklami, A., Tahiri, A., Benidire, L., El Alaoui, A., Meddich, A., Göttfert, M., \& Oufdou, K. (2019). Characterization of plant growth promoting rhizobacteria and their benefits on growth and phosphate nutrition of faba bean and wheat. Biology Open, 8(7), bio043968. https://doi.org/10.1242/bio.043968

Beech, I. B., Paiva, M., Caus, M., \& Coutinho, C. (2001). Enzymatic activity and within biofilms of sulphate-reducing bacteriaBiofilm community interactions: Change or necessity? In P. G. Gilbert, D. Allison, M. Brading, J. Verran, \& J. Walker (Eds.), Biofilm community interactions: Change or necessity (pp. 231-239).

Behera, B. C., Singdevsachan, S. K., Mishra, R. R., Sethi, B. K., Dutta, S. K., \& Thatoi, H. N. (2016). Phosphate solubilizing bacteria from mangrove soils of Mahanadi River delta, Odisha, India. World Journal of Agricultural Research, 4, 18-23.

Behera, B. C., Yadav, H., Singh, S. K., Mishra, R. R., Sethi, B. K., Dutta, S. K., \& Thatoi, H. N. (2017). Phosphate solubilization and acid phosphatase activity of Serratia sp. Isolated from mangrove soil of Mahanadi river delta, Odisha, India. Journal of Genetic Engineering and Biotechnology, 15, 169-178. https://doi.org/10.1016/j.jgeb.2017.01.003

Berninger, T., González López, Ó., Bejarano, A., Preininger, C., \& Sessitsch, A. (2018). Maintenance and assessment of cell viability in formulation of non-sporulating bacterial inoculants. Microbial Biotechnology, 11(2), 277-301. PubMed. https://doi.org/10.1111/1751-7915.12880

Bhattacharyya, C., Roy, R., Tribedi, P., Ghosh, A., \& Ghosh, A. (2020). Biofertilizers as substitute to commercial agrochemicals. In M. N. V. Prasad (Ed.), Agrochemicals Detection, Treatment and Remediation (pp. 263-290). Butterworth-Heinemann. https://doi.org/10.1016/B978-0-08-103017-2.00011-8 
Bhattacharyya, P. N., Goswami, M. P., \& Bhattacharyya, L. H. (2016). Perspective of beneficial microbes in agriculture under changing climatic scenario: A review. Journal of Phytology, $8,26-41$.

Bhattacharyya, P. N., \& Jha, D. K. (2012). Plant growth-promoting rhizobacteria (PGPR): Emergence in agriculture. Microbial Biotechnology, 28, 1327-1350.

Billah, M., Khan, M., Bano, A., Hassan, T. U., Munir, A., \& Gurmani, A. R. (2019). Phosphorus and phosphate solubilizing bacteria: Keys for sustainable agriculture. Geomicrobiology Journal, 36(10), 904-916. https://doi.org/10.1080/01490451.2019.1654043

Borgi, M. A., Saidi, I., Moula, A., Rhimi, S., \& Rhimi, M. (2020). The Attractive Serratia plymuthica BMA1 Strain With High Rock Phosphate-Solubilizing Activity and Its Effect on the Growth and Phosphorus Uptake by Vicia faba L. Plants. Geomicrobiology Journal, 37(5), 437-445. https://doi.org/10.1080/01490451.2020.1716892

Breitkreuz, C., Buscot, F., Tarkka, M., \& Reitz, T. (2020). Shifts Between and Among Populations of Wheat Rhizosphere Pseudomonas, Streptomyces and Phyllobacterium Suggest Consistent Phosphate Mobilization at Different Wheat Growth Stages Under Abiotic Stress. Frontiers in Microbiology, 10, 3109. https://doi.org/10.3389/fmicb.2019.03109

Chen, P. Y., Pekha, P. D., Arunshen, A. B., Lai, W. A., \& Young, C. C. (2006). Phosphate solubilizing bacteria from subtropical soil and their tricalcium phosphate solubilizing abilities. Applied Soil Ecology, 34, 33-41.

Chung, H., Park, M., Madhaiyan, M., Seshadri, S., Song, J., Cho, H., \& Sa, T. (2005). Isolation and characterization of phosphate solubilizing bacteria from the rhizosphere of crop plants of Korea. Soil Biology and Biochemistry, 37, 1970-1974.

Cordell, D., Drangert, J. O., \& White, S. (2009). The Story of Phosphorus: Global Food Security and Food for Thought. Global Environmental Change, 19(2), 292-305.

Dash, N., \& Dangar, T. K. (2019). Phosphate mineralization by a rice (Oryza sativa L.) rhizoplanic Enterobacter sp. American-Eurasian Journal of Sustainable Agriculture, 13(4), 1. Gale Academic OneFile.

Dash, N., Pahari, A., \& Dangar, T. K. (2017). Functionalities of Phosphate-Solubilizing Bacteria of Rice Rhizosphere: Techniques and Perspectives. In P. Shukla (Ed.), Recent Advances in Applied Microbiology. Springer. https://doi.org/10.1007/978-981-10-5275-0_7

Delfim, J., Schoebitz, M., Paulino, L., Hirzel, J., \& Zagal, E. (2018). Phosphorus availability in Wheat in Volacnic soils inoculated with Phosphate Solubilizing Bacillus thiringiensis. Sustainability, 10(1), 144. https://doi.org/10.3390/su100101441 
El-Deen, R. O. S., Abd El-Azeem, S. A. M., Elwahab, A. F. A., \& Mabrouk, S. S. (2020). Effects of Phosphate solubilizing Microorgansms on Wheat Yiled and Phosphatase Activity. Egyptian Journal of Microbiology, 55, 71-86.

Emami, S., Alikhani, H. A., Pourbabaee, A. A., Etesami, H., Motasharezadeh, B., \& Sarmadian, F. (2020). Consortium of endophyte and rhizosphere phosphate solubilizing bacteria improves phosphorous use efficiency in wheat cultivars in phosphorus deficient soils. Rhizosphere, 14, 100196. https://doi.org/10.1016/j.rhisph.2020.100196

Eramma, Mahadevaswamy, Satyanarayana, R., Ramesh, Y. M., \& Nagaraj, M. N. (2020). Isolation and Screening of Phosphate Solubilizing Bacteria from Paddy Rhizosphere Soil. International Journal of Current Microbiology and Applied Sciences, 9(2), 447-485.

Etesami, H., \& Beattie, G. (2018). Mining halophytes for plant growth-promoting halotolerant bacteria to enhance the salinity tolerance of non-halophytic crops. Frontiers in Microbiology, 9, 148.

Etesami, H., \& Maheshwari, D. K. (2018). Use of plant growth promoting rhizobacteria (PGPRs) with multiple plant growth promoting traits in stress agriculture: Action mechanisms and future prospects. Ecotoxicol Environ Saf. 156, 225-246.

Fankem, H., Nwaga, D., Deubel, A., Dieng, L., Merbach, W., \& Etoa, F. X. (2006). Occurrence and functioning of phosphate solubilizing microorganism from oil plam tree (Elaeis guineensis) rhizosphere in Cameroon. African Journal of Biotechnology, 5(24), 24502460 .

FAO. (2017). The Future of Food and Agriculture - Trends and Challenges. Rome. www.fao.org/publications

Fitriatin, B. N., Dita Fauziah, Fitriani, F. B., Ningtyas, D. M., Suryatmana, P., Hindersah, R., Setiawati, M. R., \& Simarmata, T. (2020). Biochemical activity and bioassay on maize seedling of selected indigenous phosphate-solubilizing bacteria isolated from the acid soil ecosystem. Open Agriculture, 5(1), 300-304. https://doi.org/10.1515/opag-2020-0036

García-Fraile, P., Menéndez, E., \& Rivas, R. (2015). Role of bacterial biofertilizers in agriculture and forestry. AIMS Bioengineering, 2(3), 108-205.

Goswami, D., Thakker, J. N., \& Dhandhukia, P. C. (2016). Portraying mechanics of plant growth promoting rhizobacteria (PGPR): A review. Congent Food and Agriculture, 2, 1-9.

Grady, E. N., MacDonald, J., Liu, L., Richman, A., \& Yuan, Z. C. (2016). Current knowledge and perspectives of Paenibacillus: A review. Microbial Cell Factories, 15(1), 203. 
Gyaneshwar, P., Naresh, K. G., Parekh, L. G., \& Poole, P. S. (2002). Role of soil microorganisms in improving P nutrition of plants. Plant and Soil, 245, 83-89.

Hakim, S., Mirza, B. S., Imran, A., Zaheer, A., Yasmin, S., Mubeen, F., Mclean, J. E., \& Mirza, M. S. (2020). Illumina sequencing of $16 \mathrm{~S}$ rRNA tag shows disparity in rhizobial and nonrhizobial diversity associated with root nodules of mung bean (Vigna radiata L.) growing in different habitats in Pakistan. Microbiological Research, 231, 126356. https://doi.org/10.1016/j.micres.2019.126356

Harshitha, A., Goudar, G., Krishnaraj, P. U., \& Koti, R. V. (2020). Characterization of Plant Growth Promoting Rhizobial Isolates for Pigeon Pea (Cajanus cajan [L.] Mill sp). International Journal of Current Microbiology and Applied Sciences, 9(7), 3776-3788.

Ibarra-Galeana, J. A., Castro-Martínez, C., Fierro-Coronado, R. A., Armenta-Bojórquez, A. D., \& Maldonado-Mendoza, I. E. (2017). Characterization of phosphate-solubilizing bacteria exhibiting the potential for growth promotion and phosphorus nutrition improvement in maize (Zea mays L.) in calcareous soils of Sinaloa, Mexico. Annals of Microbiology, 67(12), 801-811. https://doi.org/10.1007/s13213-017-1308-9

Jadoon, S., Afzal, A., Asad, S. A., Sultan, T., Tabassum, B., Umer, M., \& Asif, M. (2019). Plant Growth Promoting traits of Rhizobacteria isolated from Potato (Solanum tuberosum L.) and their antifungal activity against Fusarium oxysporum. The Journal of Anima; and Plant Sciences, 29(4), 1026-1036.

Jo, G. S., Kim, S. Y., Cho, J. S., \& Cheong, Y. H. (2019). Isolation and Characterization of Phosphate Solubilizing Pseudomonas species and their effect on Plant Growth Promotion. Korean Journal of Soil Science and Fertilizer, 52(4), 438-447.

Jog, R., Pandya, M., Nareshkumar, G., \& Rajkumar, S. (2014). Mechanism of phosphate solubilization and antifungal activity of Streptomyces spp. Isolated from wheat roots and rhizosphere and their application in improving plant growth. Microbiology, 160(4), 778788. https://doi.org/10.1099/mic.0.074146-0.

Jorquera, M. A., Crowley, D. E., Marschner, P., Greiner, R., Fernández, M. T., \& Romero, D. (2011). Identification of $\beta$-propeller phytase-encoding genes in culturable Paenibacillus and Bacillus spp. From the rhizosphere of pasture plants on volcanic soils. FEMS Microbiology Ecology, 75, 163-172. https://doi.org/10.1111/j.1574-6941.2010.00995

Kadmiri, I. M., Chaouqui, L., Azaroual, S. E., Sijilmassi, B., Yaakoubi, K., \& Wahby, I. (2018). Phosphate-solubilizing and auxin-producing rhizobacteria promote plant growth under 
saline conditions. Arabian Journal for Science and Engineering, 43(7), 3403-3415. https://doi.org/10.1007/s13369-017-3042-9

Kafle, A., Cope, K., Raths, R., Krishna, Y. J., Subramanian, S., Bucking, H., \& Garcia, K. (2019). Harnessing Soil Microbes to Improve Plant Phosphate Efficiency in Cropping Systems. Agronomy, 9(3), 127. https://doi.org/10.3390/agronomy9030127

Kalayu, G. (2019). Phosphate Solubilizing Microorganisms: Promising Approach as Biofertilizers. International Journal of Agronomy, 2019, 4917256. https://doi.org/10.1155/2019/4917256

Kaur, C., Selvakumar, G., \& Ganeshamurthy, A. N. (2016). Organic Acids in the Rhizosphere: Their Role in Phosphate Dissolution. In D. Singh, H. Singh, \& R. Prabha (Eds.), Microbial Inoculants in sustainable Agricultural Productivity (pp. 165-177). Springer. https://doi.org/10.1007/978-81-322-2644-4_11

Kaur, P., \& Purewal, S. S. (2019). Biofertilizers and their Role in Sustainable Agriculture. In B. Giri, R. Prasad, Q. S. Wu, \& A. Varma (Eds.), Biofertilizers for Sustainable Agriculture and Environment (Vol. 55, pp. 285-300). Springer. https://doi.org/10.1007/978-3-03018933-4_12

Kennedy, I. A., Choudhury, A. T. M. A., \& Kecskés, M. L. (2004). Non-symbiotic bacterial diazotrophs in crop-farming systems: Can their potential for plant growth promotion be better exploited? Soil Biology and Biochemistry, 36(8), 1229-1244. https://doi.org/10.1016/j.soilbio.2004.04.006

Khalid, R., Zhang, X. X., Hayat, R., \& Ahmed, M. (2020). Molecular Characteristics of Rhizobia Isolated from Arachis hypogaea grwon under Stress Envionment. Sustainability, 12(15), 6259.

Khan, A. A., Jilani, G., Akhtar, M. S., Naqvi, S. M. S., \& Rasheed, M. (2009). Phosphorus solubilizing bacteria: Occurrence, mechanisms and their role in crop production. 1(1), 4858.

Khan, M. S., Zaidi, A., Ahemad, M., Oves, M., \& Wani, P. A. (2010). Plant growth promotion by phosphate solubilizing fungi-Current perspective. Archives of Agronomy and Soil Sciences, 56, 73-98.

Kolekar, S. S., Desai, P. D., Pancahal, H. K., \& Shah, K. B. (2017). Study of phosphate solubilizing microorganisms with biofertilizer potential. International Journal of Pharma and Bio Sciences, 8, 751-757. 
Kumar, A. (2016). Phosphate solubilizing bacteria in agriculture biotechnology: Diversity, mechanism and their role in plant growth and crop yield. International Journal of Advanced Research, 4(4), 116-124.

Kumar, A., Kumar, A., \& Patel, H. (2018). Role of microbes in phosphorus availability and acquisition by plants. International Journal of Current Microbiology and Applied Sciences, 7(5), 1344-1347.

Kumar, G., \& Sarma, B. K. (2016). Eco-friendly Management of Soil-borne Plant Pathogens through Plant Growth-Promoting Rhizobacteria. SATSA Mukhapatra, 20, 167-171.

Kumar, S., Bauddh, K., Barman, S. C., \& Singh, R. P. (2014). Amendments of microbial bio fertilizers and organic substances reduces requirement of urea and DAP with enhanced nutrient availability and productivity of wheat (Triticum aestivum L.). Ecological Engineering, 71, 432-437.

Kumar, V., Singh, P., Jorquera, M. A., Sangwan, P., Verma, A. K., \& Sanjeev, A. (2013). Isolation of phytase-producing bacteria from Himalayan soils and their effect on growth and phosphorusuptake of Indian mustard (Brassica juncea). World Journal of Microbiology and Biotechnology, 29, 1361-1369.

Leghari, S. J., Wahocho, N. A., Laghari, G. M., Laghari, A. H., Bhabham, G. M., Talpur, K. A., Bhutto, T. A., Wahocho, S. A., \& Lashari, A. A. (2016). Role of nitrogen for plant growth and development: A review. Advances in Environmental Biology, 10(9), 209-219.

Li, L., Chen, R., Zuo, Z., Lv, Z., Yang, Z., Mao, W., Liu, Y., Zhou, Y., Huang, J., \& Song, Z. (2020). Evaluation and improvement of phosphate solubilization by an isolated bacterium Pantoea agglomerans ZB. World Journal of Microbiology and Biotechnology, 36(2), 27. https://doi.org/10.1007/s11274-019-2744-4

Linu, M. S., Asok, A. K., Thampi, M., Sreekumar, J., \& Jisha, M. S. (2019). Plant Growth Promoting Traits of Indigenous Phosphate Solubilizing Pseudomonas aeruginosa Isolates from Chilli (Capsicumannuum L.) Rhizosphere. Communications in Soil Science and Plant Analysis, 50(4), 444-457. https://doi.org/10.1080/00103624.2019.1566469

Liu, Y. Q., Wang, Y. H., Kong, W. L., Liu, W. H., Xie, X. L., \& Wu, X. Q. (2020). Identification, cloning and expression patterns of the genes related to phosphate solubilization in Burkholderia multivorans WS-FJ9 under different soluble phosphate levels. AMB Express, 10(1), 108. https://doi.org/10.1186/s13568-020-01032-4 
Mahidi, S. S., Hassan, G. I., Hussain, A., \& Rasool, F. (2011). Phosphorus availability issue-Its fixation and role of phosphate solubilizing bacteria in phosphate solubilization-Case study. Research Jounral of Agricultural Sciences, 2, 174-179.

Maougal, R. T., Brauman, K. A., Plassard, C., Abadie, J., Djekoun, A., \& Drevon, J. J. (2014). Bacterial capacitiesto mineralize phytate increase in the rhizosphere of nodulated common bean (Phaseolus vulgaris) under P deficiency. European Journal of Soil Biology, 62, 8-14.

Marra, L. M., Soares, C. R. F. S., de Oliveira, S. M., Ferreira, P. A. A. A., Soares, B. L., Carvalho, R. F., Lima, J. M., \& Moreira, F. M. (2012). Biological nitrogen fixation and phosphate solubilization by bacteria isolated from tropical soils. Plant and Soil, 357, 289-307.

Mehnaz, S., Arora, N. K., Mehnaz, S., \& Balestrini, R. (2016). An Overview of Globally Available Bioformulations. In Bioformulations for Sustainable Agriculture (pp. 267-281). Springer. https://doi.org/10.1007/978-81-322-2779-3_15

Midekssa, M. J., Loscher, C. R., Schmitz, R. A., \& Assefa, F. (2015). Characteriztion of phosphate solubilizing rhizobacteria from lentil growing areas of Ethipia. African Journal of Microbiology Research, 9(25), 1637-1648. https://doi.org/10.5897/AJMR2015.7473

Mihalache, G., Mihasan, M., Zamfirache, M. M., Stefan, M., \& Raus, L. (2018). Phosphate solubilizing bacteria from runner bean rhizosphere and their mechanism of action. Romanian Biotechnological Letters, 23(4), 13853-13861.

Mishra, J., \& Arora, N. K. (2016). Bioformulations for plant growth promotion and combating phytopathogens: A sustainable approach. In N. K. Arora, S. Mehnaz, \& R. Balestrini (Eds.), Bioformulations: For sustainable agriculture (pp. 3-33). Springer. https://www.researchgate.net/publication/303833637_Bioformulations_for_Plant_Growt h_Promotion_and_Combating_Phytopathogens_A_Sustainable_Approach

Mitra, D., Anđelković, S., Panneerselvam, P., Senapati, A., Vasić, T., Ganeshamurthy, A. N., Chauhan, M., Uniyal, N., Mahakur, B., \& Radha, T. K. (2020). Phosphate-Solubilizing Microbes and Biocontrol Agent for Plant Nutrition and Protection: Current Perspective. Communications in Soil Science and Plant Analysis, 51(5), 645-657. https://doi.org/10.1080/00103624.2020.1729379

Mohammad, S. K., Zaidi, A., \& Parvaze, A. W. (2007). Role of phosphate-solubilizing microorganisms in sustainable agriculture - a review. Agronomy for Sustainable Development, 27(1), 29-43.

Mohammadi, K., \& Sohrabi, Y. (2012). Bacterial Biofertilizers for Sustainable Crop production: A Review. ARPN Journal of Agricultural and Biological Science, 7(5), 307-316. 
Mukhtar, S., Zareen, M., Khaliq, Z., Mehnaz, S., \& Malik, K. A. (2020). Phylogenetic analysis of halophyte-associated rhizobacteria and effect of halotolerant and halophilic phosphatesolubilizing biofertilizers on maize growth under salinity stress conditions. Journal of Applied Microbiology, 128(2), 556-573. https://doi.org/10.1111/jam.14497

Muleta, D., Assefa, F., Börjesson, E., \& Granhall, U. (2013). Phosphate-solubilising rhizobacteria associated with Coffea arabica L. in natural coffee forests of southwestern Ethiopia. Journal of the Saudi Society of Agricultural Sciences, 12, 73-84. https://doi.org/10.1016/J.JSSAS.2012.07.002

Nagalingam, S., Nithya, T. V., Gayathri, D., Sagarika, A. S., Supriya, G., Vidya, D., Kumar, B. K., Rasool, A., \& Mir, M. I. (2020). Morhological, Biochemical and Plant Growth Promoting Characterization of Rhizobia isolated frim Root Nodule of Cajanus Cajan L. Plant Archives, 20(2), 1293-1299.

Odoh, C. K., Eze, C. N., Akpi, U. K., \& Unah, V. U. (2019). Plant growth promoting rhizobacteria (PGPR): A novel Agent for sustainable food production. American Journal of Agricultural and Biological Sciences, 14, 35-54. https://doi.org/10.3844/ajabssp.2019.35.54

Oo, K., Win, T., Khai, A., \& Fu, P. (2020). Isolation, Screening and Molecular Characterization of Multifunctional Plant Growth Promoting Rhizobacteria for a Sustainable Agriculture. American Journal of Plant Sciences, 11, 773-792. https://doi.org/10.4236/ajps.2020.116055

Oteino, N., Lally, R. D., Kiwanuka, S., Lloyd, A., Ryan, D., Germaine, K. J., \& Dowling, D. N. (2015). Plant growth promotion induced by phosphate solubilizing endophytic Pseudomonas isolates. Frontiers in Microbiology, 6, 745.

Pallavi, Chandra, D., \& Sharma, A. K. (2017). Commercial Microbial Products: Exploiting Beneficial Plant-Microbe Interaction. In D. P. Singh, H. B. Singh, \& R. Prabha (Eds.), Microbial Interactions and Agro-Ecological Impacts (Vol. 2, pp. 607-626). Springer Singapore. https://doi.org/10.1007/978-981-10-6593-4_25

Pande, A., Pandey, P., Mehra, S., Singh, M., \& Kaushik, S. (2017). Phenotypic and genotypic characterization of phosphate solubilizing bacteria and their efficiency on the growth of maize. Journal of Genetic Engineering and Biotechnology, 15(2), 379-391. PubMed. https://doi.org/10.1016/j.jgeb.2017.06.005

Panhwar, Q. A., Ali, A., Depar, N., \& Shah, J. A. (2020). Screening of Plant Growth Promoting Rhizobacteria for Sustainable Wheat (Triticum aestivum L.) Crop Production. Pakistan Journal of Botany, 52(1), 345-353. 
Parani, K., \& Saha, B. (2012). Prospects of using phosphate solubilising Pseudomonas as biofertiliser. European Journal of Biological Science, 4(2), 40-44.

Parker, D. R., Reichmann, S. M., \& Crowley, D. E. (2005). Metal Chelation in the rhizosphere. In R. W. Zobel (Ed.), Roots and soil management: Interactions between roots and the soil (pp. 57-93). American Society of Agronomy.

Parmar, P., \& Sindhu, S. S. (2013). Potassium solubilization by rhizosphere bacteria: Influence of nutritional and environmental conditions. Journal of Microbiology Research, 31(1), 2531.

Patel, D., \& Goswami, D. (2020). Phosphorus Solubilization and Mobilization: Mechanisms, Current Developments, and Future Challenges. In A. Yadav, A. Rastegari, N. Yadav, \& D. Kour (Eds.), Advances in Plant Microbiome and Sustainable Agroculture. (Vol. 20, pp. 120). Springer. https://doi.org/10.1007/978-981-15-3204-7_1

Patel, S. T., \& Minocheherhomji, F. P. (2018). Review: Plant Growth Promoting Rhizobacteria: Blessing to Agriculture. International Journal of Pure and Applied Bioscience, 6(2), 481492. http://dx.doi.org/10.18782/2320-7051.6383

Pereira, S. I. O., \& Castro, P. L. (2014). Phosphate-solubilizing rhizobacteria enhance Zea mays growth in agricultural P deficient soils. Ecological Engineering, 73, 526-535.

Pradhan, A., Pahari, A., Mohapatra, S., \& Mishra, B. B. (2017). Phosphate-Solubilizing Microorganisms in Sustainable Agriculture: Genetic Mechanism and Application (pp. 8197). Springer Nature Singapore Pte Ltd. https://doi.org/10.1007/978-981-10-7380-9_5

Qin, L., Jiang, H., Tian, J., Zhao, J., \& Liao, H. (2011). Rhizobia enhance acquisition of phosphorus from different sources by soybean plants. Plant and Soil, 349, 25-36.

Qu, L. L., Peng, C. L., \& Li, S. B. (2020). Isolation and screening of a phytate phosphatesolubilizing Paenibacillus sp. And its growth-promoting effect on rice seeding. Ying yong sheng tai xue bao = The journal of applied ecology, 31(1), 326-332. PubMed. https://doi.org/10.13287/j.1001-9332.202001.033

Rafi, M. M., Krishnaveni, M. S., \& Charyulu, P. B. B. N. (2019). Phosphate-Solubilizing Microorganisms and their emerging Role in Sustainable Agriculture. In V. Buddolla (Ed.), Recent Developments in Applied Microbiology and Biochemistry (pp. 223-233). Academic Press. https://doi.org/10.1016/B978-0-12-816328-3.00017-9

Rafique, M., Sultan, T., Ortas, I., \& Chaudhary, H. J. (2017). Enhancement of maize plant growth with inoculation of phosphate-solubilizing bacteria and biochar amendment in soil. Soil Science and Plant Nutrition, 63, 460-469. 
Rawat, J., Sanwal, P., \& Saxena, J. (2018). Towards the mechanisms of nutrient solubilization and fixation in soil system. In V. Meena (Ed.), Role of rhizospheric microbes in soil (pp. 229257). Springer. https://doi.org/10.1007/978-981-13-0044-8_8

Rfaki, A., Zennouhi, O., Aliyat, F. Z., Nassiri, L., \& Ibijbijen, J. (2020). Isolation, Selection and Characterization of Root-Associated Rock Phosphate Solubilizing Bacteria in Moroccan Wheat (Triticum aestivum L.). Geomicrobiology Journal, 37(3), 230-241. https://doi.org/10.1080/01490451.2019.1694106

Richardson, A. E., \& Simpson, R. J. (2011). Soil microorganisms mediating phosphorus availability. Plant Physiology, 159, 986-996.

Rodrigues, E. P., Rodrigues, L. S., de Oliveira, A. L. M., Baldani, V. L. D., Dos Santos, T. K. R., Urquiaga, S., \& Reis, V. M. (2008). Azospirillum amazonense inoculation: Effects on growth, yield and N2 fixation of rice (Oryza sativa L.). Plant and Soil, 302(1), 249-261.

Sadiq, H. M., Jahangir, G. Z., Nasir, I. A., Iqtidar, M., \& Iqbal, M. (2013). Isolation and characterization of phosphate-solubilizing bacteria from rhizosphere soil. Biotechnology and Biotechnological Equipment, 27(6), 4248-4255. https://doi.org/10.5504/BBEQ.2013.0091

Saleemi, M., Kiani, M. Z., Sultan, T., Khalid, A., \& Mahmood, S. (2017). Integrated effect of plant growth-promoting rhizobacteria and phosphate-solubilizing microorganisms on growth of wheat (Triticum aestivum L.) under rainfed condition. Agriculture \& Food Security, 6(1), 46. https://doi.org/10.1186/s40066-017-0123-7

Salimpour, S., Khavazi, K., Nadian, H., Besharati, H., \& Miransari, M. (2010). Enhancing phosphorous availability to canola (Brassica napus L.) using $\mathrm{P}$ solubilizing and sulfur oxidizing bacteria. Australian Journal of Crop Science, 4, 330-334.

Santana, E. B., Marques, E. L. S., \& Dias, J. C. T. (2016). Effects of phosphate-solubilizing bacteria, native microorganisms and rock dust on Jatropha curcas L. growth. Genetics and Molecular Research, 15(4), 15048729.

Sarikhani, M. R., Aliasgharzad, N., \& Khoshru, B. (2020). P Solubilizing Potential of Some Plant Growth Promoting Bacteria Used as Ingredient in Phosphatic Biofertilizers with Emphasis on Growth Promotion of Zea mays L. Geomicrobiology Journal, 37(4), 327-335. https://doi.org/10.1080/01490451.2019.1700323

Satyaprakash, M., Nikitha, T., Reddi, E. U. B., Sadhana, B., \& Vani, S. S. (2017). Phosphorous and Phosphate Solubilising Bacteria and their Role in Plant Nutrition. International Journal of Current Microbiology and Applied Sciences, 6(4), 2133-2144. 
Selvi, K. B., Paul, J. J. A., Vijaya, V., \& Saraswathi, K. (2017). Analysing the Efficiency of Phosphate Solubilizing Microorganisms by Enrichment Culture Techniques. Biochemistry and Moleculat Biology Journal, 3(1), 1-7. https://doi.org/0.21767/2471-8084.100027

Shahid, M., Hameed, S., Imram, A., Ali, S., \& Van Elsas, J. D. (2012). Root colonization and growth promotion of sunflower (Helianthus annuus L.) by phosphate solubilizing Enterobacter sp. Fs-11. World Journal of Microbiology and Biotechnology, 28, 27492758. https://doi.org/10.1007/s11274-012-1086-2

Sharma, R., Pal, J., \& Kaur, M. (2017). Isolation of phosphate solubilizing Pseudomonas strains from apple rhizosphere in the Trans Himalayan region of Himachal Pradesh, India. BioRxiv, Preprint, 193672. https://doi.org/10.1101/193672

Sharma, S. B., Sayyed, R. Z., Trivedi, M. H., \& Gobi, T. A. (2013). Phosphate solubilizing microbes: Sustainable approach for managing phosphorus deficiency in agricultural soils. SpringerPlus, 2, 587. https://doi.org/10.1186/2193-1801-2-587

Sijilmassi, Filali-Maltouf, A., Fahde, S., Ennahli, Y., Boughribil, S., Kumar, S., \& Amri, A. (2020). In-Vitro Plant Growth Promotio of Rhizobium Strains Isolated from Lentil Root Nodules under Abiotic Stresses. Sustainability, 10(7), 1006.

Sood, G., Kaushal, R., Panwar, G., \& Dhiman, M. (2018). Effect of Indigenous Plant GrowthPromoting Rhizobacteria on Wheat (Triticum aestivum L.) Productivity and Soil Nutrients. Communications in Soil Science and Plant Analysis, 50(2), 141-152. https://doi.org/10.1080/00103624.2018.1556282

Suleiman, D., Sani, A., Ambardini, S., Boer, D., \& Yanti, N. A. (2019). Isolation and Identification of Phosphate Solubilizing Bacteria (PSB) from various Plant Rhizospheres and its ability to dissolve tricalcium phosphate under in vitro condition. Bioscience Research, 16(2), 110.

Tairo, E. V., \& Ndakidemi, P. A. (2014). Micronutrients uptake in soybean (Glycine max L.) as affected by Bradyrhizobium japonicum inoculation and phosphorus (p) supplements. World Journal of Soil and Crop Sciences Research, 1(1), 1-9.

Thiruvengadam, S., Ramki, R., Rohini, S., Vanitha, R., \& Ivo, R. (2020). Isolation, Screening and Evaluation of Multifunctional Strains of High Efficient Phosphate Solubilizing Microbes from Rhizosphere Soil. Research Journal of Pharmacy and Technology, 13(4), 1823-1826. https://doi.org/10.5958/0974-360X.2020.00328.5 
Thomas, L., \& Singh, I. (2019). Microbial Biofertilizers: Types and Applications. In Biofertilizers for Sustainable Agriculture and Environment (pp. 1-19). https://doi.org/10.1007/978-3030-18933-4_1

Valverde, A., Burgos, A., Fiscella, T., Rivas, R., Velazquez, E., Rodriguez-Barrueco, C., Cervantes, E., Chamber, M., \& Igual, J. M. (2006). Differential effects of coinoculations with Pseudomonas jessenii PS06 (a phosphate-solubilizing bacterium) and Mesorhizobium ciceri C-2/2 strains on the growth and seed yield of chickpea under greenhouse and field conditions. Plant and Soil, 287, 43-50.

Varma, P. K., Uppala, S., Pavuluri, K., Chandra, K. J., Chapala, M. M., \& Kumar, K. V. K. (2017). Endophytes: Role and Functions in Crop Health. In D. Singh, H. Singh, \& R. Prabha (Eds.), Plant-Microbe Interactions in Agro-Ecological Perspectives (pp. 291-310). Springer.

Vazquez, P., Holguin, G., Puente, M., Lopez-cortes, A., \& Bashan, Y. (2000). Phosphate solubilizingmicroorganisms associated with the rhizosphere of mangroves in a semi-arid coastal lagoon. Biology and Fertility of Soils, 30, 460-468.

Vessey, J. K. (2003). Plant growth promoting rhizobacteria as biofertilizers. Plant and Soil, 255, $571-568$.

Vyas, R. V., Panpatte, D. G., Jhala, Y. K., \& Shelat, H. N. (2017). Wonders of Microbes in Agriculture for Productivity and Sustainability. In D. G. Panpatte, Y. K. Jhala, R. V. Vyas, \& H. N. Shelat (Eds.), Microbes for Sustainable Crop Production (Vol. 1, pp. 1-23). Springer Singapore. https://doi.org/10.1007/978-981-10-6241-4_1

Walia, A., Guleira, S., Chauhan, A., \& Mehta, P. (2017). Endophytic Bacteria: Role in Phosphate Solubilization. In D. K. Maheshwari \& K. Annapuma (Eds.), Endophytes: Crop Productivity and Protection (Vol. 16, pp. 61-93). Springer. https://doi.org/10.1007/978-3319-66544-3_4

Walpola, B. C., \& Yoon, M. (2013). Phosphate solubilizing bacteria: Assessment of their effect on growth promotion and phosphorous uptake of mung bean (Vigna radiata [L.] R. Wilczek). Chilean Journal of Agricultural Research, 73, 275-281.

Wang, Y. Y., Li, P. S., Zhang, B. X., Wang, Y. P., Meng, J., Gao, Y. F., He, X. M., \& Hu, X. M. (2020). Identification of Phosphate-solubilizing Microorganisms and Determination of Their Phosphate-solubilizing Activity and Growth-promoting Capability. BioResources, 15(2), 2560-2578.

Yao, A. V., Bochow, H., Karimov, S., Boturov, U., Sanginboy, S., \& Sharipov, A. K. (2006). Effect of FZB 24® Bacillus subtilis as a biofertilizer on cotton yields in field tests. Archives 
of Phytopathology and Plant Protection, 39(4), 323-328. https://doi.org/10.1080/03235400600655347

Yaqub, F., \& Shahzad, S. (2011). Efficacy and persistence of micobial antagonists against Sclerotium rolfsii under field conditions. Pakistan Journal of Botany, 43(5), 2627-2734.

Yi, Y., Huang, W., \& Ge, Y. (2008). Exopolysaccharide: A novel important factor in the microbial dissolution of tricalcium phosphate. World Journal of Microbiology and Biotechnology, 24, 10589-11065.

Yildirim, E., Karlidag, H., Turan, M., Dursun, A., \& Goktepe, F. (2011). Growth, Nutrient Uptake, and Yield Promotion of Broccoli by Plant Growth Promoting Rhizobacteria with Manure. HortScience, 46(6), 932-936.

You, M., Fang, S., MacDonald, J., Xu, J., \& Yuan, Z. C. (2020). Isolation and characterization of Burkholderia cenocepacia CR318, a phosphate solubilizing bacterium promoting corn $\begin{array}{llll}\text { growth. } & \text { Microbiological Research, } & 233, & \end{array}$ https://doi.org/10.1016/j.micres.2019.126395

Youssef, M. M. A., \& Eissa, M. F. M. (2014). Biofertilizers and their role in management of plant parasitic nematodes. A review. Journal of Biotechnology and Pharmaceutical Research, $5,1-6$.

Zaidi, A., Khan, M. S., Ahemad, M., \& Oves, M. (2009). Plant growth promotion by phosphate solubilizing bacteria. Acta Microbiology and Immunology, 56, 263-284.

Zayed, M. S. (2012). Improvement of growth and nutritional quality of Moringa oleifera using different biofertilizers. Annals of Agricultural Science, 57, 53-62. https://doi.org/10.1016/j.aoas.2012.03.004

Zhang, J., Wang, P., Fang, L., Zhang, Q. A., Yan, C., \& Chen, J. (2017). Isolation and characterization of phosphate-solubilizing bacteria from mushroom residues and their effect on tomato plant growth promotion. Polish Journal of Microbiology, 66(1), 57-65.

Zhao, K., Penttinen, P., Zhang, X., Ao, X., Liu, M., Yu, X., \& Chen, Q. (2014). Maize rhizosphere in Sichuan, China, hosts plant growth promoting Burkholderia cepacia with phosphate solubilizing and antifungal abilities. Microbiological Research, 169(1), 76-82. https://doi.org/10.1016/j.micres.2013.07.003

Zhu, F., Qu, L., Hong, X., \& Sun, X. (2011). Isolation and characterization of a phosphatesolubilizing halophilic bacterium Kushneria sp. YCWA18 from Daqiao Saltern on the coast of Yellow Sea of China. Evidence-Based Complementary and Alternative Medicine, 6,615032 . 
